\title{
Effective Downy Mildew Management in Basil Using Resistant Varieties, Environment Modifications, and Fungicides
}

\author{
Jaimin S. Patel, ${ }^{1,+}$ Christian A. Wyenandt, ${ }^{2}$ and Margaret T. McGrath ${ }^{3}$ \\ ${ }^{1}$ Cooperative Research and Extension, Lincoln University in Missouri, Jefferson City, MO 65101 \\ ${ }^{2}$ Department of Plant Biology, Rutgers University, Rutgers Agricultural Research and Extension Center (RAREC), Bridgeton, NJ 08302 \\ ${ }^{3}$ Plant Pathology and Plant-Microbe Biology Section, School of Integrative Plant Science, Cornell University, Long Island Horticultural \\ Research and Extension Center, Riverhead, NY 11901
}

Accepted for publication 16 April 2021.

\begin{abstract}
Considerable progress has been made in managing Peronospora belbahrii, an oomycete pathogen that causes basil downy mildew, since 2007, when it was first detected in the United States. Conventional fungicides have been registered and shown effective against $P$. belbahrii in replicated experiments in recent years. Unfortunately, because of their specific modes of action and $P$. belbahrii biology, some are at risk for resistance development, which has been documented outside the United States. Sweet basil varieties have been developed and commercialized, with most exhibiting good to high levels of resistance to basil downy mildew. Knowledge about conditions favorable for infection and disease development has resulted in the identification of cultural practices for managing basil downy mildew in the greenhouse. Practices being implemented include fans to move leaves, thus

preventing water deposition and decreasing relative humidity, lighting at night to mitigate sporulation, and temperature modification to suppress disease development. Although downy mildew can be more effectively managed today, growers still experience losses, particularly when conditions are highly favorable for disease development. None of the organic fungicides or programs tested have provided adequate control for susceptible varieties, and limited testing has been done on resistant varieties to date. This review aims to summarize effective basil downy mildew management tools, in particular downy mildew-resistant varieties, environment modifications, and fungicide applications.

Keywords: basil downy mildew, environment modification, Peronospora belbahrii, oomycetes, resistant varieties, fungicides
\end{abstract}

Basil downy mildew (BDM), caused by the oomycete Peronospora belbahrii, is an economically important disease of Ocimum spp. worldwide. This disease can result in $100 \%$ yield loss in field- and greenhouse-grown fresh-market basil, because any symptoms on leaves render the crop unmarketable. The disease was first detected in Uganda in 1932 (Hansford 1933) and reemerged in Switzerland in 2001 (Belbahri et al. 2005). After its reemergence, it quickly spread throughout Europe, the Americas, Middle East, and Asia (Babadoost 2010; Bastidas et al. 2016; Belbahri et al. 2005; Blomquist et al. 2009; Celar and Kos 2019; Chen et al. 2010; Choi et al. 2016; Cohen et al. 2013b; Coosemans 2004; Denton et al. 2015; Garibaldi et al. 2004, 2005; Grice et al. 2017; Henricot et al. 2010; Hu et al. 2018; Kanetis et al. 2014; Khateri et al. 2007; Kong et al. 2015; Martínez de la Parte et al. 2010; McGrath et al. 2010a, b; McLeod et al. 2006; Nagy and Horvath 2011; Petrželová et al. 2015; Porta-Puglia and

\section{${ }^{\dagger}$ Corresponding author: J. S. Patel; patelj@lincolnu.edu}

Funding: Funding for research conducted by the authors on managing basil downy mildew was provided in part by the United States Department of Agriculture Specialty Crops Research Initiative project award 2011-51181-30646 and award 2018-51181-28383 to Rutgers University, in concert with consortium partners Cornell University, University of Florida, and University of Massachusetts.

The author(s) declare no conflict of interest.

(C) 2021 The American Phytopathological Society
Mifsud 2006; Roberts et al. 2009; Ronco et al. 2008; Šafránková and Holkova 2014; Saude et al. 2013; Silva et al. 2019; Smith and Urrea 2018; Voglmayr and Piatek 2008; Wick and Brazee 2009). Contaminated seeds were likely the initial source of $P$. belbahrii in many areas. Progress has been made since a previous review article was published with an emphasis on BDM management strategies in the United States (Wyenandt et al. 2015). Scientists worldwide have investigated new, innovative strategies to develop additional BDM management tools. This review aims to summarize effective BDM management tools, which include downy mildew-resistant varieties, environment modifications, and fungicide use.

\section{Downy Mildew-Resistant Varieties}

Researchers have evaluated numerous Ocimum spp. for their susceptibility to BDM in the past decade. In general, sweet basil (O. basilicum) is the most susceptible (Djalali Farahani-Kofoet et al. 2014; Homa et al. 2016; Wyenandt et al. 2010), citrus basil (O. citriodorum) develops fewer disease symptoms (Damicone 2010; Mersha et al. 2012a; Wyenandt et al. 2010), and spice types (O. americanum, O. basilicum var. americanum) are the most resistant to BDM (Damicone 2010; Römer et al. 2010; Wyenandt et al. 2010). Thai basil (O. basilicum var. tenuiflorum, $O$. basilicum var. thyrsiflorum), cinnamon basil (O. basilicum 'Cinnamon'), and 'Red Rubin' basil (O. basilicum) were found to be less susceptible to BDM than other O. basilicum varieties (Mersha et al. 2012a; Wyenandt et al. 2010). Ocimum spp. 
mentioned in Table 1 can be a natural source of resistance in BDM breeding programs. In recent years, breeding efforts have been made to find and introduce natural sources of resistance from other Ocimum spp. Römer et al. (2010) reported O. americanum, $O$. canum, and $O$. micranthemum as resistant genotypes. Pyne et al. (2015) reported a resistant sweet basil (O. basilicum) variety, 'Mrihani' (MRI), and showed that BDM resistance in MRI could be introduced to sweet basil without the issue of sterility barriers as seen in other Ocimum spp. crosses. Later, Pyne et al. (2017) showed that one major quantitative trait locus (QTL) (dm11.1) and two minor QTLs $(d m 9.1$ and $d m 14.1)$ are associated with downy mildew resistance in an MRI $\times$ SB22 F2 basil population. Ben-Naim et al. (2015) crossed 27 highly resistant individual plants with susceptible sweet basil 'Peri'. Two crosses generated highly resistant F1 progenies, 24 crosses generated moderately resistant $\mathrm{F} 1$ plants, and one cross resulted in susceptible F1 generation. Further, Ben-Naim et al. (2018) generated F1 plants from the interspecific hybridization (PI $500945 \times$ sweet basil), which had a dominant resistant gene $(\mathrm{Pbl})$. However, these plants were sterile. To resolve the sterility problem, F1 plants were pollinated with fertile pollen of a susceptible sweet basil. The backcross progeny (BCs1) to the susceptible parent plants were generated by rescuing embryos in vitro. The BCs1 plants suggested that resistance in F1 is controlled by a pair of dominant genes $\left(P b 1 A\right.$ and $\left.P b l A^{\prime}\right)$. The partial fertile BCs1 plants were self-pollinated or backcrossed to sweet basil to generate BCs1-F2 or BCs2 plants, respectively. Accelerated breeding of resistance is now possible following the recent establishment of a CRISPR/Cas9-mediated gene editing system for targeted mutagenesis in sweet basil. It was used to generate mutants with complete knockout of the susceptibility gene ObDMRI at the first generation of transgenic plants and transgene-free homozygous mutants in the second generation (Navet and Tian 2020). Zhang et al. (2021) modified sweet basil downy mildew susceptibility gene homoserine kinase (ObHSK) using CRISPR-gene editing technology and demonstrated that gene-edited plants can reduce susceptibility to downy mildew.

Breeding has resulted in sweet basil varieties with intermediate to high levels of BDM resistance being introduced for global markets in recent years. These varieties include 'Rutgers Obsession DMR', 'Rutgers Passion DMR', 'Rutgers Thunderstruck DMR', 'Rutgers Devotion DMR' (Rutgers University, U.S. patent no. US 10,159,212 B1); 'UF16-23-2' (Amazel Basil, Proven Winners, U.S. patent no. PP30,917) (Clark et al. 2019); and 'Prospera DMR F1' (developed by Bar Ilan University) and 'Prospera DMR', 'Prospera Compact DMR', 'Prospera Italian Large Leaf DMR', and 'Prospera Premium F1 Basil' (released by Genesis Seeds, U.S. patent no. US 2019/0364774). These were preceded by varieties with lower levels of BDM resistance: 'Eleonora' (released by Enza Zaden Beheer BV, U.S. patent no. US 9,668,435 B2), and 'Everleaf' (released by PanAmerican Seeds). The newer BDM-resistant varieties have exhibited good to

\begin{tabular}{|c|c|c|c|c|}
\hline \multicolumn{5}{|c|}{$\begin{array}{c}\text { TABLE } 1 \\
\text { Ocimum spp. showing a resistant phenotype against basil downy mildew }\end{array}$} \\
\hline \multirow[b]{2}{*}{ Species } & \multicolumn{2}{|c|}{ Mean disease severity } & \multirow[b]{2}{*}{$n / N^{b}$} & \multirow[b]{2}{*}{ Reference } \\
\hline & Rating scale & $\%^{\mathrm{a}}$ & & \\
\hline O. americanum var. americanum & $0-0.96^{\mathrm{c}}$ & & $7 / 7$ & Ben-Naim et al. 2015 \\
\hline O. americanum var. pilosum & $0-0.46^{\mathrm{c}}$ & & $9 / 10$ & Ben-Naim et al. 2015 \\
\hline O. basilicum var. anisatum & $0.38-0.57^{\mathrm{c}}$ & & $3 / 4$ & Ben-Naim et al. 2015 \\
\hline O. kilimandscharicum & $0^{\mathrm{c}}$ & & $1 / 1$ & Ben-Naim et al. 2015 \\
\hline O. kilimandscharicum $\times O$. basilicum & $0.58^{\mathrm{c}}$ & & $2 / 2$ & Ben-Naim et al. 2015 \\
\hline O. tenuiflorum & $0-0.79^{c}$ & & $5 / 8$ & Ben-Naim et al. 2015 \\
\hline O. gratissimum & $0^{\mathrm{c}}$ & & $2 / 2$ & Ben-Naim et al. 2015 \\
\hline O. gratissimum var. gratissimum & $0^{\mathrm{c}}$ & & $2 / 2$ & Ben-Naim et al. 2015 \\
\hline O. basilicum var. americanum & & 0 & $1 / 2$ & Djalali Farahani-Kofoet et al. 2014 \\
\hline O. campechianum & & 0 & $1 / 1$ & Djalali Farahani-Kofoet et al. 2014 \\
\hline O. canum & & 0 & $1 / 1$ & Djalali Farahani-Kofoet et al. 2014 \\
\hline O. micranthum & & 0 & $1 / 1$ & Djalali Farahani-Kofoet et al. 2014 \\
\hline O. tenuiflorum & & 0 & $1 / 1$ & Djalali Farahani-Kofoet et al. 2014 \\
\hline O. gratissimum & & 0 & $1 / 1$ & Djalali Farahani-Kofoet et al. 2014 \\
\hline O. americanum & $0^{\mathrm{d}}$ & & $3 / 3$ & Homa et al. 2016 \\
\hline O. tenuiflorum & $0^{\mathrm{d}}$ & & $1 / 1$ & Homa et al. 2016 \\
\hline O. $\times$ africanum & $0.2-0.8^{\mathrm{d}}$ & & $4 / 4$ & Homa et al. 2016 \\
\hline O. americanum $\times O$. basilicum & $0^{\mathrm{d}}$ & & $1 / 1$ & Wyenandt et al. 2010 \\
\hline Ocimum sp. & $0^{\mathrm{d}}$ & & $1 / 2$ & Wyenandt et al. 2010 \\
\hline
\end{tabular}

${ }^{\mathrm{a}}$ Based on $\%$ leaf area sporulating.

${ }^{\mathrm{b}}$ Number of accessions/genotypes $(n)$ with listed rating scale range (in the second column) out of a total number of tested accession/genotypes ( $N$ ) of the same species.

${ }^{\mathrm{c}}$ Based on a categorical scale 0 to 4 , where 0 is highly resistant and 4 is highly susceptible.

${ }^{\mathrm{d}}$ Based on a categorical scale 0 to 3 , where 0 is highly resistant and 3 is highly susceptible. 
excellent control in field evaluations (Table 2). Additionally, Rutgers Thunderstruck DMR, Rutgers Devotion DMR, and Rutgers Obsession DMR did not show any $P$. belbahrii sporulation in a greenhouse trial (Hausbeck and Harlan 2019). The BDM-resistant sweet basil varieties are recommended for use with preventative fungicide applications, and also environmental manipulation for greenhouse basil to ensure the required high level of control is achieved.

\section{Environment Modification for BDM Management}

Temperature, relative humidity, and $\mathrm{CO}_{2}$. Spore germination is an essential event for infection. Patel et al. (2015b) demonstrated that $P$. belbahrii sporangia could germinate in the tested temperature range of 5 to $20^{\circ} \mathrm{C}$. However, spore germination was maximum at $10^{\circ} \mathrm{C}$ and increasingly reduced at 15,20 , and $5^{\circ} \mathrm{C}$. Also, maximum spore germination was reached by 8 to $9 \mathrm{~h}$ of incubation at the optimum temperature of $10^{\circ} \mathrm{C}$ in an in vitro study (Patel et al. 2015b). P. belbahrii colonization of basil leaves can occur at 8.5 to $30^{\circ} \mathrm{C}$ with a 12 -h photoperiod (Cohen et al. 2017).

The most favorable temperature for $\mathrm{BDM}$ development is $20^{\circ} \mathrm{C}$, when relative humidity $(\mathrm{RH})$ is $100 \%$ (Garibaldi et al. 2007). However, BDM can develop in the temperature range of 5 to $30^{\circ} \mathrm{C}$, with the least disease occurrence at 5 and $30^{\circ} \mathrm{C}$ (Djalali Farahani-Kofoet et al. 2014). High temperature $\left(>25^{\circ} \mathrm{C}\right)$ has been shown to negatively affect disease severity (Elad et al. 2016). A temperature range of 20 to $23^{\circ} \mathrm{C}$ was reported to be the optimum for sporulation of $P$. belbahrii in darkness (Cohen et al. 2013a; Garibaldi et al. 2007). Similarly, disease severity was negatively related to high soil temperature $\left(>21^{\circ} \mathrm{C}\right)$ and $\mathrm{RH}$ in the range of 65 to $85 \%$ (Elad et al. 2016). When symptomless plants were moved from high temperature $\left(45\right.$ to $\left.48^{\circ} \mathrm{C}\right)$ to moderate temperature $\left(22^{\circ} \mathrm{C}\right)$ with $\mathrm{RH}>95 \%$, plants became severely diseased and showed $P$. belbahrii sporulation, suggesting that disease development is suppressed at high temperature. Although the air temperature was above $40^{\circ} \mathrm{C}$, the leaf surface median temperature was below $30^{\circ} \mathrm{C}$. This suggests that reduction in disease severity may be due to temperature effect on the host rather than on the pathogen. An increase in root zone temperature from 22 to $31^{\circ} \mathrm{C}$ while keeping the aboveground air temperature set to $22.5^{\circ} \mathrm{C}$ reduced the area under the disease progress curve (Elad et al. 2016).

Spore formation by $P$. belbahrii is maximum at 97.6 to $100 \%$ $\mathrm{RH}$ but is significantly lower at $94.6 \% \mathrm{RH}$ and nearly null at $85 \% \mathrm{RH}$. Infected basil plants in a dew chamber for $9 \mathrm{~h}$ showed sporulation on about $73 \%$ of the leaf area. Plants that were dried for $10 \mathrm{~min}$ after the onset of dew showed sporulation on $35 \%$ of the leaf area, and those dried for 3 to $6 \mathrm{~h}$ showed no sporulation (Cohen and Ben-Naim 2016). P. belbahrii spore germination requires $\geq 2 \mathrm{~h}$ of incubation in water at 15 to $20^{\circ} \mathrm{C}$ (Cohen and Ben-Naim 2016). A leaf wetness/dew period of $\geq 6 \mathrm{~h}$ at $15^{\circ} \mathrm{C}$ (Cohen and Ben-Naim 2016) and $20^{\circ} \mathrm{C}$ (Garibaldi et al. 2007) is effective for successful infection of basil leaves. Maximum infection occurs with a dew period of $8 \mathrm{~h}$ at 11.5 to $15.5^{\circ} \mathrm{C}$, whereas trace infection occurs at 5 and $28.5^{\circ} \mathrm{C}$ with the same dew period (Cohen et al. 2017). Interrupting the dew period with a 10-min dry period at 3 or $4 \mathrm{~h}$ postinoculation had a strong negative effect on infection (Cohen and Ben-Naim 2016). The dry period created by fanning the plants showed that free leaf moisture is vital for successful infection. Nocturnal fanning can keep $\mathrm{RH} \leq 95 \%$, which reduces sporulation. This practice could also shorten the dew period and thus the chances of new infections occurring. In contrast, spore formation requires $>85 \% \mathrm{RH}$ but not free leaf moisture (Cohen and Ben-Naim 2016).

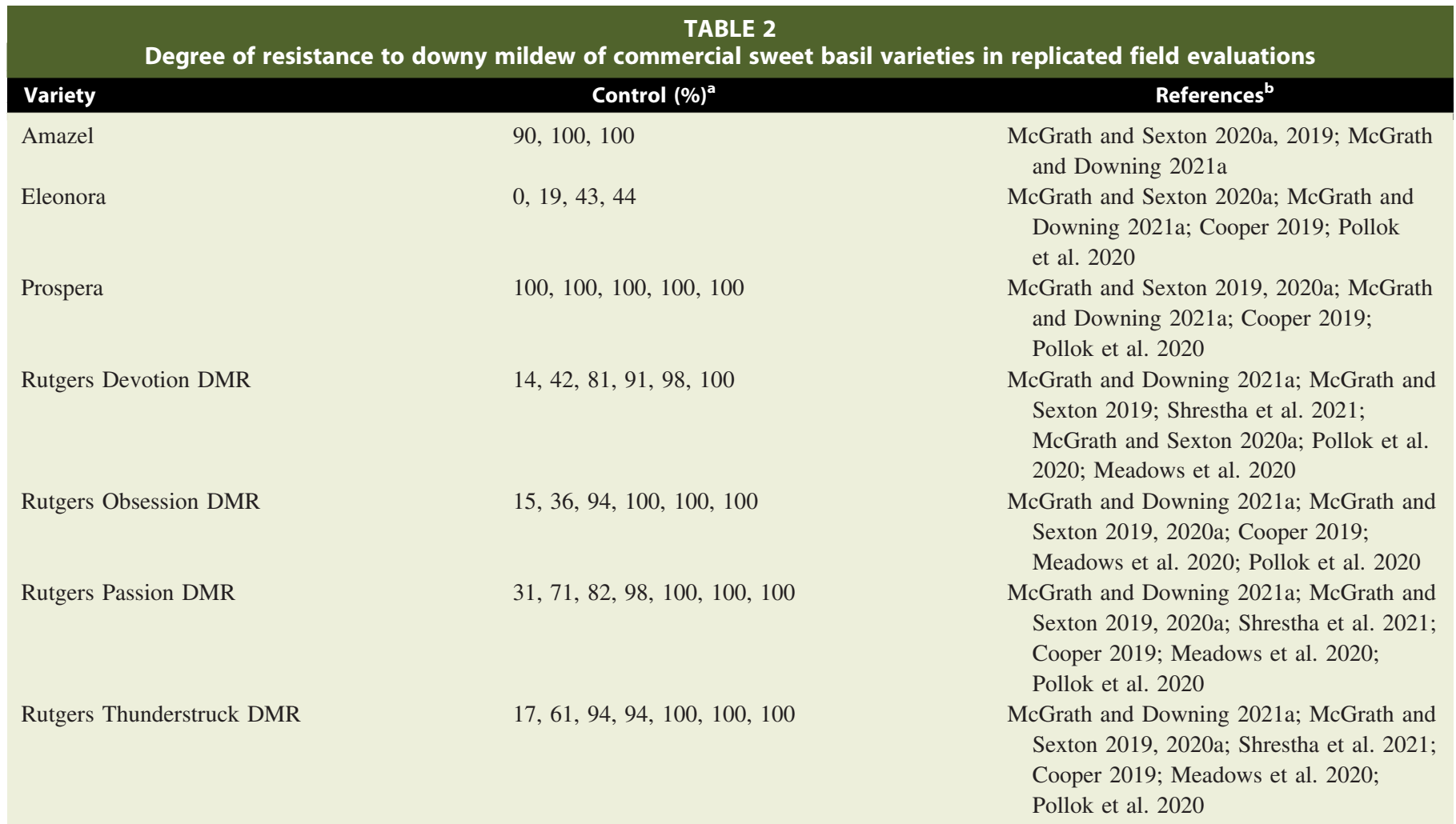

\footnotetext{
${ }^{a}$ Control calculated as percent reduction in incidence of symptomatic leaves relative to the susceptible variety from the last evaluation date of each experiment
}

${ }^{\mathrm{b}}$ References are listed in order corresponding to the adjacent control (\%) values in the row. 
Survival of freshly produced spores is negatively affected by longer exposure periods to high temperatures. The spores were killed after exposure to 45,35 to 45 , and 25 to $45^{\circ} \mathrm{C}$ for 48,72 , and $96 \mathrm{~h}$, respectively (Cohen et al. 2017). Exposure to $40^{\circ} \mathrm{C}$ for 6 to $9 \mathrm{~h}, 35^{\circ} \mathrm{C}$ for $17 \mathrm{~h}$, and $30^{\circ} \mathrm{C}$ for $27 \mathrm{~h}$ killed $P$. belbahrii mycelia inside infected basil leaves. Cohen and Rubin (2015) demonstrated that covering net houses containing infected basil plants with transparent polyethylene sheets could raise the daily maximal temperature up to $58^{\circ} \mathrm{C}$. Such heating of net houses for a few hours for 1 to 3 successive days killed the pathogen and suppressed disease progress while enhancing plant growth.

Gilardi et al. (2016) demonstrated that an increase in $\mathrm{CO}_{2}$ to twice the standard level (400 to $450 \mathrm{ppm}$ ) under moderate temperature $\left(18\right.$ to $\left.22^{\circ} \mathrm{C}\right)$ resulted in a significant increase in BDM incidence and severity. A similar rise in $\mathrm{CO}_{2}$ concentration from 450 to $850 \mathrm{ppm}$ in a temperature range of 22 to $26^{\circ} \mathrm{C}$ and 26 to $30^{\circ} \mathrm{C}$ also significantly increased disease severity. Disease incidence at 800 to $850 \mathrm{ppm} \mathrm{CO}_{2}$ concentration at the highest temperature tested $\left(26\right.$ to $\left.30^{\circ} \mathrm{C}\right)$ was not significantly different $(P>0.05)$ from incidence at 400 to $450 \mathrm{ppm} \mathrm{CO}_{2}$ concentration at 18 to $22^{\circ} \mathrm{C}$ because 26 to $30^{\circ} \mathrm{C}$ is higher than the optimum temperature (20 to $23^{\circ} \mathrm{C}$ ) for disease and spore development (Elad et al. 2016; Garibaldi et al. 2007). The global atmospheric $\mathrm{CO}_{2}$ is increasing every year (https://www.esrl.noaa.gov/gmd/ccgg/trends/ and https:// scrippsco2.ucsd.edu/), suggesting that subtropical and temperate zones may see an increase in BDM severity. The studies indicate that controlled environment facilities should consider keeping the $\mathrm{CO}_{2}$ level between 400 and $450 \mathrm{ppm}$.

Light/darkness. Downy mildew pathogens are known to produce asexual spores during the night when it is dark and humid (Cohen et al. 2013a; Patel et al. 2016; Weston 1920; Yarwood 1937). Many experiments have been conducted to understand asexual sporulation under different light spectra and different light/dark regimes.

Cool white $(\mathrm{CW})$ fluorescent light at 6,21 , and $35 \mu \mathrm{mol} \cdot \mathrm{m}^{-2} \cdot \mathrm{s}^{-1}$ completely inhibited sporulation of $P$. belbahrii irrespective of the leaf surface exposed to the light. However, the exposed leaf surface had a reduced number of spores under $2 \mu \mathrm{mol} \cdot \mathrm{m}^{-2} \cdot \mathrm{s}^{-1} \mathrm{CW}$ fluorescent light (Cohen et al. 2013a). Light treatment does not inhibit sporangiophore development (Cohen et al. 2017). A repeated trial with five treatments-(i) 14-h light (L) followed by 10-h darkness (D) (long day); (ii) 14-h L followed by 3-h D, 4-h L, 3-h D (3-h break); (iii) 14-h L followed by 2-h D, 2-h L, 2-h D, 2-h L, 2-h D (2-h break); (iv) continuous light; and (v) greenhouse conditions with 16-h light-revealed that continuous light completely controlled sporulation (López-López et al. 2014). The 3-h break (second treatment) and continuous light had significantly fewer spores than the long day treatment (first treatment), suggesting that avoiding nighttime darkness could suppress $P$. belbahrii sporulation.

In 2013, a laboratory experiment demonstrated that photosynthetic photon flux density (PPFD) of 5 and $10 \mu \mathrm{mol} \cdot \mathrm{m}^{-2} \cdot \mathrm{s}^{-1}$ red light-emitting diodes (LEDs) with a peak wavelength of $625 \mathrm{~nm}$ $\left(\lambda_{\max }=625 \mathrm{~nm}\right)$ is more effective than the same PPFD of blue $\operatorname{LED}\left(\lambda_{\max }=440 \mathrm{~nm}\right)$ and green LED $\left(\lambda_{\max }=500 \mathrm{~nm}\right)$ in suppressing production of $P$. belbahrii spores (Cohen et al. 2013a). Further, Patel et al. (2016) demonstrated a practical use of nighttime red $\operatorname{LED}\left(\lambda_{\max }=625 \mathrm{~nm}\right)$ lighting at $12 \mu \mathrm{mol} \cdot \mathrm{m}^{-2} \cdot \mathrm{s}^{-1}$ to significantly inhibit $P$. belbahrii sporulation and reduce disease severity in a greenhouse setting. It was also evident from Cohen et al. (2013a) that exposing the lower basil leaf surface to a low level of light (blue, green, or red at $5 \mu \mathrm{mol} \cdot \mathrm{m}^{-2} \cdot \mathrm{s}^{-1}$ ) is more effective for inhibiting sporulation than exposing the upper surface of infested basil leaves. Because red and blue LEDs are among commonly used commercial horticultural LED lighting, Radetsky et al. (2020) examined nighttime blue $\left(\lambda_{\max }=458 \mathrm{~nm}\right)$ and red $\left(\lambda_{\max }=670 \mathrm{~nm}\right)$ LEDs at $\approx 12$ and $\approx 60 \mu \mathrm{mol} \cdot \mathrm{m}^{-2} \cdot \mathrm{s}^{-1}$ using 10 -h continuous and intermittent nighttime treatments to whole plants to suppress $P$. belbahrii sporulation. Continuous LED lighting resulted in lower sporulation than both intermittent treatments. For the given treatment profile related to dark treatment, the spore counts under red LED exposures were generally lower than, but not statistically different from, blue LED exposures. Also, two intermittent treatments had similar effects on suppressing $P$. belbahrii sporulation (Radetsky et al. 2020). It is worth noting that Radetsky et al. (2020) applied $\approx 60 \mu \mathrm{mol} \cdot \mathrm{m}^{-2} \cdot \mathrm{s}^{-1}$ (total dose $=\approx 2.2 \mathrm{~mol} \cdot \mathrm{m}^{-2}$. night $^{-1}$ ), which is much less than daylight $\left(\approx 8\right.$ to $30 \mathrm{~mol} \cdot \mathrm{m}^{-2} \cdot$ night $^{-1}$ ) required for plant photosynthesis. Exposing inoculated whole basil plants (two to three pairs of leaves) repeatedly for 11 nights to red light at $60 \mu \mathrm{mol} \cdot \mathrm{m}^{-2} \cdot \mathrm{s}^{-1}$ resulted in very little spore production (Fig. 1). In addition to downy mildew suppression, 10 -h exposure during nighttime to $\approx 60 \mu \mathrm{mol} \cdot \mathrm{m}^{-2} \cdot \mathrm{s}^{-1}$ of red LEDs can increase basil growth and thus yield (Patel et al. 2018). Although a laboratory detached leaf test showed nearly complete suppression of sporulation at $10 \mu \mathrm{mol} \cdot \mathrm{m}^{-2} \cdot \mathrm{s}^{-1}$ with red LEDs (Cohen et al. 2013a), similar suppression of spores in a whole plant may require exposure to higher PPFD than $10 \mu \mathrm{mol} \cdot \mathrm{m}^{-2} \cdot \mathrm{s}^{-1}$ depending upon the density of vegetative growth of the plants. Cohen et al. (2013a) found that light is only effective in suppressing $P$. belbahrii sporulation at $\geq 15^{\circ} \mathrm{C}$. This suggests that light may be affecting responsible protein complexes or enzymes in either basil, $P$. belbahrii, or both at $\geq 15^{\circ} \mathrm{C}$ to inhibit spore formation.

Ultraviolet (UV) light is well known for its ability to control various human and plant pathogens (Gates 1929; Patel et al. 2017, 2020). Patel et al. (2017) investigated preinoculation treatment of basil plants with UV-B $\left(\lambda_{\max }=292 \mathrm{~nm} ; 1,368 \mathrm{~J} \cdot \mathrm{m}^{-2}\right.$ over a period of $120 \mathrm{~min}$ ) for BDM management. Basil plants exposed to UV-B for 3 and 6 days before $P$. belbahrii inoculation exhibited reduced sporulation compared with nonexposed

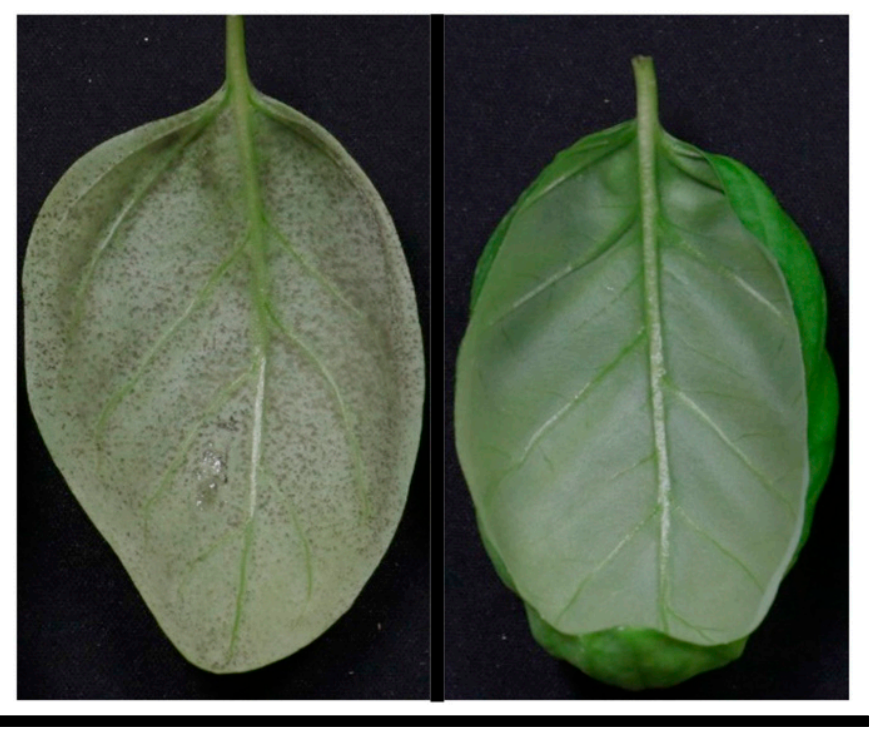

FIGURE 1

A basil leaf exposed to nighttime darkness (left) shows plentiful spore formation, and a basil leaf exposed to red light (right; $\lambda_{\max }=625 \mathrm{~nm} ; \approx 60$ $\mu \mathrm{mol} \cdot \mathrm{m}^{-2} \cdot \mathrm{s}^{-1}$ ) for $10 \mathrm{~h}$ displays no spore formation of Peronospora belbahrii. These basil leaves were picked from whole plants that were exposed to nighttime darkness or red lighting. 
plants. This suggested that UV treatments can induce downy mildew resistance in the plant. However, the UV-B dose used in that study caused burning of basil leaves. More research needs to be done to determine the appropriate preinoculation UV dose to reduce downy mildew severity without damaging leaves.

\section{Fungicide Efficacy}

More than 45 field and greenhouse trials have been conducted to test the efficacy of new, existing, and experimental crop protection products against BDM. Fungicides belonging to more than 16 different Fungicide Resistance Action Committee (FRAC) groups have been tested by researchers for their efficacy against BDM. Many of these conventional products provided varying levels of efficacy (Babadoost 2021; Babadoost and DeYoung 2012; Homa et al. 2014; McGrath 2020; McGrath and Hunsberger 2011, 2012; McGrath and LaMarsh 2013, 2014; Mersha et al. 2012b; Novaes et al. 2014; Patel et al. 2013, 2014, 2015a, c; Raid and Sui 2011; Raid et al. 2011a, b, 2013, 2020; Standish et al. 2020, 2021; Scheufele et al. 2015; Wyenandt 2020; Wyenandt and Simon 2014, 2020). However, in general, foliar application of products containing azoxystrobin, fenamidone, mandipropamid, oxathiapiprolin, phosphorus acids, and cyazofamid at 7-day intervals provided significant disease control over the untreated control in field or greenhouse conditions (Babadoost and DeYoung 2012; Homa et al. 2014; McGrath and LaMarsh 2014; Novaes et al. 2014; Patel et al. 2013, 2015a, c; Raid and Sui 2011; Raid et al. 2011a, b, 2013; Wyenandt 2020).

Several trials have included fungicides that are not currently labeled. Soil drenching with oxathiapiprolin at 0.13 liter/ha and mefenoxam at 1.17 liters/ha provided 60 and 97\% disease control, respectively, over untreated basil plants 23 days after treatments (Raid 2015a; Raid et al. 2017). Also, drenching with oxathiapiprolin followed by foliar application of mandipropamid, cyazofamid, or azoxystrobin provided more than $50 \%$ disease control over the untreated control (Raid 2015b, c, d). Seed treatment with oxathiapiprolin at 0.073 and 0.146 liter/ha showed significantly reduced downy mildew severity in basil seedlings up to 29 days after planting (Patel et al. 2015a). Foliar applications of systemic acquired resistance inducers, such as acibenzolar- $S$-methyl (ASM, Actigard 50WG), DL-3-aminobutyric acid, isonicotinic acid, salicylic acid, sodium salicylate, and glucohumate complex (Glucoinductor + GlucoActivator, $\mathrm{N} 4 \%, \mathrm{P}_{2} \mathrm{O}_{5} 18 \%$ ), were evaluated for management of BDM (Gilardi et al. 2013; Mersha and Zhang 2012; Mersha et al. 2012c, f). Only ASM and glucohumate complex significantly reduced disease severity.

Tank mixes and alternation of fungicides. More than 30 tank mixes of conventional fungicides have been evaluated as foliar applications. These trials included tank mixes of fungicides belonging to at least 12 different FRAC groups (Babadoost and DeYoung 2012, 2013, 2014, 2015; McGrath 2016b; McGrath and LaMarsh 2013, 2014; Mersha et al. 2012b, c; Patel et al. 2015a; Raid and Sui 2011; Raid et al. 2011b; Standish et al. 2020). Seventy-one percent of these tank mixes showed more than $80 \%$ disease control over untreated plants, irrespective of the FRAC group chosen for a tank mix (data not shown). Similarly, more than 60 treatments consisting of alternations of fungicides have been assessed as foliar applications (Babadoost 2016, 2019, 2020; Babadoost and DeYoung 2013, 2014, 2015; Babadoost and Sulley 2018; McGrath 2016b, c; McGrath and LaMarsh 2015; Raid 2011; Raid et al. 2011b; Wyenandt 2020; Wyenandt and Simon 2014). Sixty-one percent of these 60 treatments provided more than $80 \%$ control of BDM over untreated controls (data not shown). These results document that the current recommended practice of applying fungicides that are in different FRAC groups in alteration or as tank mixes is an effective strategy for managing BDM.

Fungicides for organic basil cultivation. At least 20 separate trials have been conducted to evaluate various fungicides suitable for use in organic basil cultivation (Allen and Patrie 2012; Allen and Saska 2013; Babadoost and DeYoung 2012; Homa et al. 2014; McGrath 2016a, c; McGrath and Downing 2021b; McGrath and LaMarsh 2013, 2014, 2015; McGrath and Hunsberger 2011, 2012; McGrath and Sexton 2017, 2020b; Mersha et al. 2012d, e; Patel et al. 2013, 2014; Raid 2017; Scheufele et al. 2015; Wyenandt and Simon 2014, 2020). Most fungicides failed to effectively control BDM. Very few fungicides reduced BDM to a moderate level (25 to $75 \%$ control) when applied to BDM-susceptible varieties (McGrath and Sexton 2017; Mersha et al. 2012e; Patel et al. 2013, 2014; Raid 2017). Such moderate levels of reduction in BDM are unacceptable, as it would not result in a salable fresh-market basil crop. Control was achieved with fungicides applied to a resistant variety (McGrath and Downing 2021b).

Fungicide resistance. Mefenoxam-resistant isolates of $P$. belbahrii have been identified in Israel (Cohen et al. 2013b) and Italy (Collina et al. 2016; Pintore et al. 2016a). Eleven of 13 isolates of $P$. belbahrii from Italy were found to be resistant in a whole plant study (Collina et al. 2016). In a separate study, disease severity caused by resistant isolates on basil plants sprayed with $100 \mu \mathrm{g} / \mathrm{ml}$ (corresponding to recommended field dose) $24 \mathrm{~h}$ before and after pathogen inoculation, and $200 \mu \mathrm{g} / \mathrm{ml} 24 \mathrm{~h}$ before pathogen inoculation, was similar to the untreated control (Pintore et al. 2016b). These mefenoxam-resistant isolates were collected from basil seeds or basil leaves (Collina et al. 2016; Pintore et al. 2016b), suggesting that the resistant pathogen may be easily spread if such seeds or leaves are shipped to various parts of the world.

\section{Management Strategies for BDM}

An integrated approach with multiple practices is considered key to successfully manage BDM. Planting pathogen-free seed is an important management practice for field- or greenhousegrown basil. It is especially critical for winter production in controlled environments when there is no field production of basil that could serve as a source of $P$. belbahrii spores. Several downy mildew-resistant sweet basil varieties are now commercially available that have shown good to excellent resistance to BDM in field trials in the United States (Table 2). They also have the leaf shape, texture, and flavor, plant architecture, stem strength, and other horticultural characteristics required to satisfy most markets. Additional downy mildew-resistant varieties are being developed and will need to be evaluated in field and greenhouse trials across the United States and elsewhere. These downy mildew-resistant varieties should be considered as the first line of defense against BDM. Utilizing knowledge about epidemiology of $P$. belbahrii to create an environment unfavorable for infection and sporulation is an effective and sustainable strategy for BDM management in controlled production facilities, including greenhouses, high tunnels, and vertical farming systems. Specific practices include (i) keeping $\mathrm{RH}$ in the plant canopy below $85 \%$ to prevent infection, (ii) running fans to move leaves during a dew/leaf wetness period to prevent infections, (iii) exposing plants to nighttime red lighting, and (iv) keeping air temperature $\geq 30^{\circ} \mathrm{C}$. Conventional fungicides are another important BDM management tool. To ensure success, 


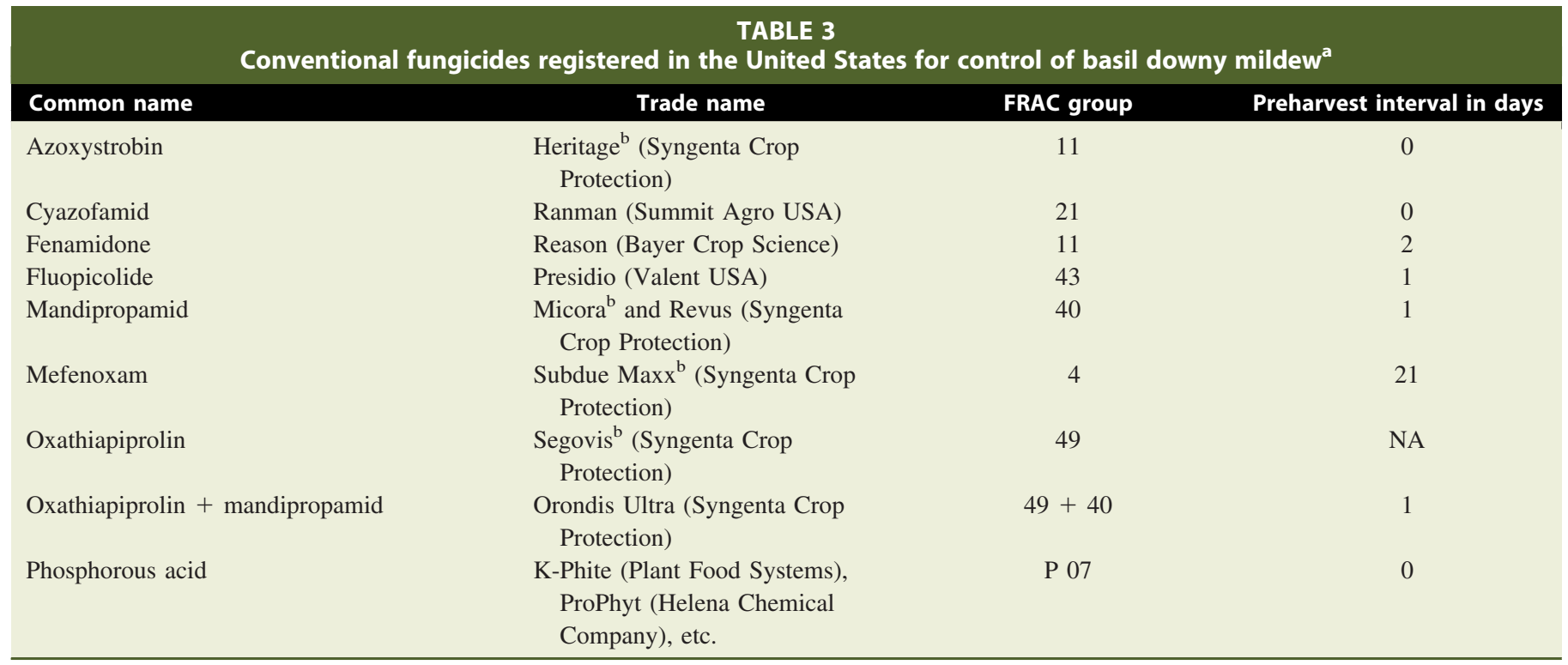

\footnotetext{
${ }^{a}$ The listing does not imply any recommendation, but it is provided solely as a reference. The listed products may not be registered in all states. Fungicide label must be read before application. FRAC = Fungicide Resistance Action Committee.

${ }^{\mathrm{b}}$ Fungicide only permitted for use in greenhouse and outdoor structures (e.g., nurseries). Subdue Maxx and Segovis only permitted for use on plants for retail sale for home and garden (residential) plantings.
}

applications need to be made on a preventative schedule at least once a week, and more often when disease pressure is very high. Fortunately, fungicides belonging to several different FRAC groups are registered for BDM (Table 3), enabling use of tank mixes and alternations to effectively manage BDM while reducing chances for fungicide resistance development. Unfortunately, organic fungicides tested so far have been shown to be ineffective for BDM when applied to susceptible or intermediately resistant sweet basil varieties. Additional research is warranted to test organic fungicides applied to newer resistant varieties. A national monitoring program for BDM (https://basil.agpestmonitor.org/) enables growers to know where and when BDM is observed and thus when fungicide applications are needed. The program has an alert system that sends out an e-mail or text to subscribers when a report is logged within the distance that the subscriber selected from their location.

\section{Industry Perspective on Managing BDM}

Information obtained from a December 2020 through February 2021 survey revealed that growers are better able to manage BDM using the strategies described above, but several remain unsatisfied. Most of the 76 growers responding to questions are producing basil conventionally in a greenhouse (76\%), while $16 \%$ are producing basil organically in a greenhouse, 5\% conventionally outdoors, and $3 \%$ organically outdoors. They see BDM every year $(25 \%)$, most years $(16 \%)$, sporadically $(47 \%)$, or never $(12 \%)$. One grower commented he has not seen BDM since he started to grow resistant varieties. Only resistant varieties are being grown by $28 \%$, both resistant and susceptible by $39 \%, 8 \%$ responded they only grow susceptible varieties because resistant ones do not meet market needs, and $25 \%$ have not tried resistant varieties yet. Fungicides are applied routinely on a preventive schedule by $31 \%$, routinely starting after symptoms are seen by $6 \%$, while $24 \%$ sometimes apply fungicides and $38 \%$ do not apply fungicides. Environmental manipulation was described as very important by $73 \%$, somewhat important by $20 \%$, and not important by only $8 \%$. Some growers commented this was not feasible or too expensive for their operation.
Of 49 respondents to a survey conducted after a virtual basil workshop in December 2020, 61\% indicated BDM is being managed more effectively now than about 6 years ago. The reason for this is new resistant varieties (23\%), new fungicides $(10 \%)$, both new resistant varieties and fungicides $(23 \%)$, and these plus greenhouse environmental manipulation (32\%). Respondents included growers (21), extension specialists, seed company representatives, consultants, and gardeners. Growers rated how satisfied they are with their ability to manage BDM as 1 for very satisfied (7\%), $2(11 \%), 3(39 \%), 4(32 \%)$, and 5 for very unsatisfied $(11 \%)$.

\section{Conclusion}

BDM now can be managed effectively in greenhouse and field crops by selecting pathogen-free seed of resistant varieties, monitoring occurrence, applying fungicides, and making the greenhouse environment unfavorable for infection, leaf colonization, and sporulation by $P$. belbahrii. Current ability to manage BDM is due to several advancements made since 2007, when BDM first occurred in the United States: varieties with good to excellent level of resistance have been developed, new fungicides have been registered, and knowledge about the pathogen has increased. Additional resistant varieties are needed to satisfy all market demands, and it is anticipated that $P$. belbahrii will evolve resistance to fungicides and $P$. belbahrii races will be able to overcome major resistance genes in the United States, as has occurred in other countries (Ben-Naim and Weitman 2021).

\section{Acknowledgments}

The authors thank OSRAM and CREE, who supported lighting experiments at the Lighting Research Center (LRC).

\section{Literature Cited}

Allen, J. E., and Patrie, A. 2012. Evaluation of organic control products for basil downy mildew, 2011. Plant Dis. Manag. Rep. 6:V073.

Allen, J. E., and Saska, M. 2013. Basil downy mildew control using organic fungicides and nitrogen fertilization rate, 2012. Plant Dis. Manag. Rep. 7:V045. 
Babadoost, M. 2010. Downy mildew of basil in Illinois. (Abstr.). Phytopathology 100(Suppl.):S9.

Babadoost, M. 2016. Evaluating effectiveness of selected fungicides for control of downy mildew of basil in Illinois, 2015. Plant Dis. Manag. Rep. 10:V102.

Babadoost, M. 2019. Evaluating effectiveness of selected fungicides for control of downy mildew of basil in Illinois, 2018. Plant Dis. Manag. Rep. 13:V028.

Babadoost, M. 2020. Evaluating effectiveness of selected fungicides for control of downy mildew of basil in Illinois, 2019. Plant Dis. Manag. Rep. 14:V069.

Babadoost, M. 2021. Evaluating effectiveness of selected fungicides for control of downy mildew of basil in Illinois, 2020. Plant Dis. Manag. Rep. 15:V086.

Babadoost, M., and DeYoung, A. 2012. Efficacy of selected fungicides for control of downy mildew of basil in Illinois, 2011. Plant Dis. Manag. Rep. 6:V131.

Babadoost, M., and DeYoung, A. 2013. Efficacy of selected fungicides for control of downy mildew of basil in Illinois, 2012. Plant Dis. Manag. Rep. 7:V140.

Babadoost, M., and DeYoung, A. 2014. Evaluating efficacy of selected fungicides for control of downy mildew of basil in Illinois, 2013. Plant Dis. Manag. Rep. 8:V282.

Babadoost, M., and DeYoung, A. 2015. Evaluating efficacy of selected fungicides for control of downy mildew of basil in Illinois, 2014. Plant Dis. Manag. Rep. 9:V118

Babadoost, M., and Sulley, S. 2018. Efficacy of selected fungicides for control of downy mildew of basil in Illinois, 2017. Plant Dis. Manag. Rep. 12:V107.

Bastidas, M. R., Picazo, L. S., Amador, B. M., Garibay, A. N., Barragan, H. L., and Montiel, L. G. H. 2016. First report of Peronospora belbahrii on sweet basil in Baja California Sur, Mexico. J. Phytopathol. 164:122124

Belbahri, L., Calmin, G., Lefort, F., and Pawlowski, J. 2005. Phylogenetic analysis and real time PCR detection of a presumbably undescribed Peronospora species on sweet basil and sage. Mycol. Res. 109:12761287.

Ben-Naim, Y., Falach, L., and Cohen, Y. 2015. Resistance against basil downy mildew in Ocimum species. Phytopathology 105:778-785.

Ben-Naim, Y., Falach, L., and Cohen, Y. 2018. Transfer of downy mildew resistance from wild basil (Ocimum americanum) to sweet basil (O. basilicum). Phytopathology 108:114-123.

Ben-Naim, Y., and Weitman, M. 2021. Joint action of $\mathrm{Pbl}$ and $\mathrm{Pb2}$ provides dominant complementary resistance against new races of Peronospora belbahrii (basil downy mildew). Phytopathology. doi: 10.1094/PHYTO02-21-0065-R.

Blomquist, C. L., Rooney-Latham, S., and Nolan, P. A. 2009. First report of downy mildew on field-grown sweet basil caused by a Peronospora sp. in San Diego County, California. Plant Dis. 93:968.

Celar, F. A., and Kos, K. 2019. Basil downy mildew (Peronospora belbahrii Thines) also in Slovenia. Pages 342-347 in: Zbornik predavanj in referatov, 14. slovensko posvetovanje o varstvu rastlin $\mathrm{z}$ mednarodno udeležbo, 5.-6. marec 2019, Maribor, Slovenija 2019.

Chen, C. H., Huang, J. H., and Hsieh, T. F. 2010. First report of Peronospora belbahrii causing downy mildew on basil. Plant Pathol. Bull. 19:177-180.

Choi, Y. J., Choi, I. Y., Lee, K. J., and Shin, H. D. 2016. First report of downy mildew caused by Peronospora belbahrii on sweet basil (Ocimum basilicum) in Korea. Plant Dis. 100:2335.

Clark, D. G., Adam, M., and Shannon, B. 2019. Basil plant named 'UF1623-2'. Patent assigned to Florida Foundation Seed Producers, Inc. Patent no. PP30917.

Cohen, Y., and Ben-Naim, Y. 2016. Nocturnal fanning suppresses downy mildew in sweet basil. PLoS One 11:e0155330.

Cohen, Y., Ben-Naim, Y., Falach, L., and Rubin, A. E. 2017. Epidemiology of basil downy mildew. Phytopathology 107:1149-1160.

Cohen, Y., and Rubin, A. E. 2015. Daytime solar heating controls downy mildew Peronospora belbahrii in sweet basil. PLoS One 10:e126103.

Cohen, Y., Vaknin, M., Ben-Naim, Y., and Rubin, A. E. 2013a. Light suppresses sporulation and epidemics of Peronospora belbahrii. PLoS One 8:e81282.

Cohen, Y., Vaknin, M., Ben-Naim, Y., Rubin, A. E., Galperin, M., Silverman, D., Bitton, S., and Adler, U. 2013b. First report of the occurrence and resistance to mefenoxam of Peronospora belbahrii, causal agent of downy mildew of basil (Ocimum basilicum) in Israel. Plant Dis. 97:692.
Collina, M., Merighi, M., Turan, C., Pirondi, A., Minuto, G., and Brunelli, A. 2016. First report of resistance of Peronospora belbahrii, causal agent of downy mildew of basil, to mefenoxam in Italy. Plant Dis. 100:1787.

Cooper, J. B. 2019. An evaluation of eight basil cultivars for downy mildew resistance in Virginia. Master's thesis. Virginia Polytechnic Institute and State University, Blacksburg, VA. https://vtechworks.lib.vt.edu/bitstream/ handle/10919/96224/Jason\%20Cooper\%20Basil\%20Project\%20Report.pdf? sequence $=1 \&$ isAllowed $=y$ (accessed January 5, 2021).

Coosemans, J. 2004. First report of Peronospora lamii, downy mildew on basil (Ocimum basilicum) in Belgium. Parasitica 60:27.

Damicone, J. P. 2010. Downy mildew on basil. Oklahoma State University Extension Pest e-alerts. http://entoplp.okstate.edu/pddl/2010/PA9-35.pdf (accessed January 6, 2021).

Denton, G. J., Beal, E., Denton, J. O., and Clover, G. 2015. First record of downy mildew, caused by Peronospora belbahrii, on Solenostemon scutellarioides in the UK. New Dis. Rep. 31:14.

Djalali Farahani-Kofoet, R., Römer, P., and Grosch, R. 2014. Selecting basil genotypes with resistance against downy mildew. Sci. Hortic. (Amsterdam) 179:248-255.

Elad, Y., Omer, C., Nisan, Z., Harari, D., Goren, H., Adler, U., Silverman, D., and Biton, S. 2016. Passive heat treatment of sweet basil crops suppresses Peronospora belbahrii downy mildew. Ann. Appl. Biol. 168:373-389.

Garibaldi, A., Bertetti, D., and Gullino, M. L. 2007. Effect of leaf wetness duration and temperature on infection of downy mildew (Peronospora sp.) of basil. J. Plant Dis. Prot. 114:6-8.

Garibaldi, A., Minuto, A., and Gullino, M. L. 2005. First report of downy mildew caused by Peronospora sp. on basil (Ocimum basilicum) in France. Plant Dis. 89:683.

Garibaldi, A., Minuto, A., Minuto, G., and Gullino, M. L. 2004. First report of downy mildew on basil (Ocimum basilicum) in Italy. Plant Dis. 88:312.

Gates, F. L. 1929. A study of the bacterial action of ultraviolet light. J. Gen. Physiol. 13:231-248.

Gilardi, G., Demarchi, S., Garibaldi, A., and Gullino, M. L. 2013. Management of downy mildew of sweet basil (Ocimum basilicum) caused by Peronospora belbahrii by means of resistance inducers, fungicides, biocontrol agents and natural products. Phytoparasitica 41:59-72.

Gilardi, G., Pugliese, M., Chitarra, W., Ramon, I., Gullino, M. L., and Garibaldi, A. 2016. Effect of elevated atmospheric $\mathrm{CO}_{2}$ and temperature increases on the severity of basil downy mildew caused by Peronospora belbahrii under phytotron conditions. J. Phytopathol. 164:114-121.

Grice, K., Sun, G., and Trevorrow, P. 2017. Basil downy mildew management options - Is it seedborne? Agri-Science Queensland Innovation Opportunity. http://era.daf.qld.gov.au/id/eprint/6386/7/H\%26FS\%20$\% 20$ Basil\%20Downy\%20Mildew\%20\%28Grice\%29\%20FINAL.pdf (accessed February 15, 2021)

Hansford, C. G. 1933. Annual report of the mycologist. Rev. Appl. Mycol. $12: 421-422$.

Hausbeck, M. K., and Harlan, B. R. 2019. Evaluation of newly-released basil cultivars for resistance to downy mildew in the greenhouse, 2018. Plant Dis. Manag. Rep. 13:OT021.

Henricot, B., Denton, J., Scrace, J., Barnes, A. V., and Lane, C. R. 2010. Peronospora belbahrii causing downy mildew disease on Agastache in the UK: A new host and location for the pathogen. Plant Pathol. 59:801.

Homa, K., Barney, W. P., Ward, D. L., Wyenandt, C. A., and Simon, J. E. 2014. Evaluation of fungicides for the control of Peronospora belbahrii on sweet basil in New Jersey. Plant Dis. 98:1561-1566.

Homa, K., Barney, W. P., Ward, D. L., Wyenandt, C. A., and Simon, J. E. 2016. Morphological characteristics and susceptibility of basil species and cultivars to Peronospora belbahrii. HortScience 51:1389-1396.

Hu, B., Li, Z., Hu, M., Sun, H., Zheng, J., and Diao, Y. 2018. Outbreak of downy mildew caused by Peronospora belbahrii on Ocimum basilicum var. polosum in China. New Dis. Rep. 37:1.

Kanetis, L., Vasiliou, A., Neophytou, G., Samouel, S., and Tsaltas, D. 2014. First report of downy mildew caused by Peronospora belbahrii on sweet basil (Ocimum basilicum) in Cyprus. Plant Dis. 98:283.

Khateri, H., Calmin, G., Moarrefzadeh, N., Belbahri, L., and Lefort, F. 2007. First report of downy mildew caused by Peronospora sp. on basil in northern. Iran. J. Plant Pathol. 89:S70.

Kong, X. Y., Wang, S., Wan, S. L., Xiao, C. L., Luo, F., and Liu, Y. 2015. First report of downy mildew on basil (Ocimum basilicum) in China. Plant Dis. 99:1642-1643.

López-López, A., Koller, M., Herb, C., and Scharer, H. J. 2014. Influence of light management on the sporulation of downy mildew on sweet basil. II International Symposium on Organic Greenhouse Horticulture 1041: 213-219. 
Martínez de la Parte, E., Perez-Vicente, L., Bernal, B., and Garcia, D. 2010. First report of Peronospora sp. on sweet basil (Ocimum basilicum) in Cuba. Plant Pathol. 59:800.

McGrath, M. T. 2016a. Evaluation of biopesticides for downy mildew in sweet basil, 2015. Plant Dis. Manag. Rep. 10:V034.

McGrath, M. T. 2016b. Evaluation of fungicides for downy mildew in sweet basil, 2015. Plant Dis. Manag. Rep. 10:V039.

McGrath, M. T. 2016c. Evaluation of organic and conventional fungicide programs for downy mildew in sweet basil, 2015. Plant Dis. Manag. Rep. 10:V033.

McGrath, M. T. 2020. Efficacy of conventional fungicides for downy mildew in field-grown sweet basil in the US. Plant Dis. 104:2967-2972.

McGrath, M. T., and Downing, C. T. 2021a. Evaluation of commercial cultivars of sweet basil resistant to downy mildew, 2020. Plant Dis. Manag. Rep. 15:V069.

McGrath, M. T., and Downing, C. T. 2021b. Evaluation of conventional and organic biopesticides applied with organic coppers for downy mildew in sweet basil, 2020. Plant Dis. Manag. Rep. 15:V077.

McGrath, M. T., and Hunsberger, L. K. 2011. Evaluation of biopesticides for managing downy mildew in basil, 2010. Plant Dis. Manag. Rep. 5:V098.

McGrath, M. T., and Hunsberger, L. K. 2012. Evaluation of biopesticides for managing downy mildew in basil, 2011. Plant Dis. Manag. Rep. 6:V099.

McGrath, M. T., and LaMarsh, K. A. 2013. Evaluation of fungicides for managing downy mildew in basil, 2012. Plant Dis. Manag. Rep. 7:V015.

McGrath, M. T., and LaMarsh, K. A. 2014. Evaluation of fungicides for managing downy mildew in basil, 2013. Plant Dis. Manag. Rep. 8:V191.

McGrath, M. T., and LaMarsh, K. A. 2015. Evaluation of organic and conventional fungicide programs for downy mildew in sweet basil, 2014. Plant Dis. Manag. Rep. 9:V026.

McGrath, M. T., and Sexton, Z. F. 2017. Evaluation of biopesticides and an organic copper fungicide for downy mildew in sweet basil, 2016. Plant Dis. Manag. Rep. 11:V030.

McGrath, M. T., and Sexton, Z. F. 2019. Evaluation of commercial cultivars of sweet basil resistant to downy mildew, 2018. Plant Dis. Manag. Rep. 13:V115.

McGrath, M. T., and Sexton, Z. F. 2020a. Evaluation of commercial cultivars of sweet basil resistant to downy mildew, 2019. Plant Dis. Manag. Rep. 14:V071.

McGrath, M. T., and Sexton, Z. F. 2020b. Evaluation of organic fungicides for downy mildew in sweet basil, 2019. Plant Dis. Manag. Rep. 14:V083.

McGrath, M. T., Wyenandt, A., and Simon, J. E. 2010a. Downy mildew wars: A monitoring program can help growers determine if the basil downy mildew pathogen is present in their area. Grow. Produce 10:8.

McGrath, M. T., Wyenandt, C. A., Raid, R. N., Babadoost, M., and Wick, R. L. 2010b. Occurrence of basil downy mildew in the eastern US in 2009. (Abstr.). Phytopathology 100(Suppl.):S196.

McLeod, A., Coertze, S., and Mostert, L. 2006. First report of a Peronospora species on sweet basil in South Africa. Plant Dis. 90:1115.

Meadows, S. J., Sharpe, S. R., and Meadows, I. M. 2020. Evaluation of basil varieties for resistance to downy mildew in North Carolina, 2019. Plant Dis. Manag. Rep. 14:V156.

Mersha, Z., and Zhang, S. 2012. Response of basil varieties to Peronospora belbahrii after foliar treatment with acibenzolar-S-methyl in the greenhouse. Plant Dis. Manag. Rep. 6:V153.

Mersha, Z., Zhang, S., and Fu, Y. 2012a. Field evaluation of basil cultivars for resistance to downy mildew in South Florida, winter 2011. Plant Dis. Manag. Rep. 6:V152.

Mersha, Z., Zhang, S., and Fu, Y. 2012b. Effect of rate and application pattern of Prophyt and Quadris tank mix for control of downy mildew in field grown basil, spring 2011. Plant Dis. Manag. Rep. 6:V087.

Mersha, Z., Zhang, S., and Fu, Y. 2012c. Efficacy of 3-aminobutanoic acid with and without fungicide combination for control of downy mildew in field grown basil, spring, 2011. Plant Dis. Manag. Rep. 6:V029.

Mersha, Z., Zhang, S., and Mo, X. 2012d. Evaluation of application timing of biologicals and biofungicides for control of downy mildew on basil, 2010. Plant Dis. Manag. Rep. 6:V060.

Mersha, Z., Zhang, S., and Mo, X. 2012e. Evaluation of biologicals and biorationals for control of basil downy mildew under greenhouse conditions, 2010. Plant Dis. Manag. Rep. 6:V059.

Mersha, Z., Zhang, S., and Raid, R. N. 2012f. Evaluation of systemic acquired resistance inducers for control of downy mildew on basil. Crop Prot. 40:83-90.

Nagy, G., and Horvath, A. 2011. Occurrence of downy mildew caused by Peronospora belbahrii on sweet basil in Hungary. Plant Dis. 95:1034.

Navet, N., and Tian, M. 2020. Efficient targeted mutagenesis in allotetraploid sweet basil by CRISPR/Cas9. Plant Direct 4:e00233.
Novaes, M. I. C., Patel, J. S., and Zhang, S. 2014. Evaluation of oxathiapiprolin (QGU42) at different rates for management of downy mildew of basil under greenhouse conditions. Plant Dis. Manag. Rep. 8:V208.

Patel, J. S., Costa de Novaes, M. I., and Zhang, S. 2015a. Evaluation of new compound oxathiapiprolin for control of downy mildew in basil. Plant Health Prog. 16:165-172.

Patel, J. S., Costade Novaes, M. I., Barbier, M., and Paret, M. 2014. Efficacy of biopesticides and difenconazole for managing downy mildew of basil, 2013. Plant Dis. Manag. Rep. 8:V207.

Patel, J. S., Costade Novaes, M. I., Barbier, M., and Zhang, S. 2013. Evaluation of biopesticides for managing downy mildew of basil, 2013. Plant Dis. Manag. Rep. 7:V147.

Patel, J. S., Radetsky, L., Nagare, R., and Rea, M. S. 2020. Nighttime application of UV-C to control cucumber powdery mildew. Plant Health Prog. 21:40-46.

Patel, J. S., Radetsky, L., Plummer, T., Bierman, A., Gadoury, D. M., and Rea, M. 2017. Pre-inoculation treatment of basil plants with ultraviolet-B radiation induces resistance to downy mildew. (Abstr.) Phytopathology 107:S5.51.

Patel, J. S., Radetsky, L., and Rea, M. S. 2018. The value of red light at night for increasing basil yield. Can. J. Plant Sci. 98:1321-1330.

Patel, J. S., Zhang, S., and de Novaes, M. I. 2015b. Factors affecting sporangial germination of Peronospora belbahrii, a causal organism of basil downy mildew. (Abstr.). Phytopathology 105:108.

Patel, J. S., Zhang, S., and Fu, Y. 2015c. Evaluation of Zorvec as seed treatment or foliar spray for management of downy mildew of basil, 2013. Plant Dis. Manag. Rep. 9:OT009.

Patel, J. S., Zhang, S. A., and McGrath, M. T. 2016. Red light increases suppression of downy mildew in basil by chemical and organic products. J. Phytopathol. 164:1022-1029.

Petrželová, I., Kitner, M., Dolezalova, I., Ondrej, V., and Lebeda, A. 2015. First report of basil downy mildew caused by Peronospora belbahrii in the Czech Republic. Plant Dis. 99:418.

Pintore, I., Gilardi, G., Gullino, M. L., and Garibaldi, A. 2016a. Risposta di popolazioni di Peronospora belbahrii a concentrazioni crescenti di Metalaxyl-M. Prot. Colt. 9:59-60.

Pintore, I., Gilardi, G., Gullino, M. L., and Garibaldi, A. 2016b. Detection of mefenoxam-resistant strains of Peronospora belbahrii, the causal agent of basil downy mildew, transmitted through infected seeds. Phytoparasitica 44:563-569.

Pollok, J. R., Rideout, S. L., Wyenandt, C. A., Garcia-Gonzalez, J. F., Sutton, K. L., and Curtis, J. T., Jr. 2020. Evaluation of basil cultivars resistance to downy mildew infection in Virginia, 2019. Plant Dis. Manag. Rep. 14:V036.

Porta-Puglia, A., and Mifsud, D. 2006. First record of downy mildew caused by Peronospora sp. on basil in Malta. J. Plant Pathol. 88:124.

Pyne, R., Honig, J., Vaiciunas, J., Koroch, A., Wyenandt, C., Bonos, S., and Simon, J. 2017. A first linkage map and downy mildew resistance QTL discovery for sweet basil (Ocimum basilicum) facilitated by double digestion restriction site associated DNA sequencing (ddRADseq). PLoS One 12:e0184319.

Pyne, R. M., Koroch, A. R., Wyenandt, C. A., and Simon, J. E. 2015. Inheritance of resistance to downy mildew in sweet basil. J. Am. Soc. Hortic. Sci. 140:396-403.

Radetsky, L., Patel, J. S., and Rea, M. S. 2020. Continuous and intermittent light at night, using red and blue LEDs to suppress basil downy mildew sporulation. HortScience 55:483-486.

Raid, R. N. 2011. Evaluation of BAS-651 for control of basil downy mildew, spring 2010. Plant Dis. Manag. Rep. 5:V046.

Raid, R. N. 2015a. Evaluation of Orondis applied as a seedling drench for control of basil downy mildew, spring 2014. Plant Dis. Manag. Rep. 9:V113.

Raid, R. N. 2015b. Evaluation of foliar fungicides in combination with Orondis seedling drench application for management of downy mildew of sweet basil, spring 2015. Plant Dis. Manag. Rep. 9:V115.

Raid, R. N. 2015c. Evaluation of foliar fungicides in combination with a mefenoxam seedling drench application for management of downy mildew on sweet basil, spring 2015. Plant Dis. Manag. Rep. 9:V116.

Raid, R. N. 2015d. Evaluation of Ridomil applied as a seedling drench for control of basil downy mildew, spring 2014. Plant Dis. Manag. Rep. 9:V114.

Raid, R. N. 2017. Evaluation of low-risk fungicides and host plant resistance for control of basil downy mildew, 2016. Plant Dis. Manag. Rep. 11:V045. 
Raid, R. N., Hartman, D., and Reis, K. 2020. Evaluation of the fungicide picarbutrazox for control of downy mildew on sweet basil, Spring 2019. Plant Dis. Manag. Rep. 14:V039.

Raid, R. N., Raid, S., and Hartman, D. 2013. Evaluation of fungicides for control of downy mildew on sweet basil. Plant Dis. Manag. Rep. 7:V146.

Raid, R. N., and Sui, D. 2011. Evaluation of fungicides for control of basil downy mildew, fall 2010. Plant Dis. Manag. Rep. 5:V157.

Raid, R. N., Sui, D., and Zhang, S. 2011a. Comparison of five fungicides of dissimilar modes of action for control of downy mildew on sweet basil, spring 2010. Plant Dis. Manag. Rep. 5:V047.

Raid, R. N., Sui, D., and Zhang, S. 2011b. Evaluation of registered fungicides for control of downy mildew on sweet basil, spring 2010. Plant Dis. Manag. Rep. 5:V048.

Raid, R. N., Vital, J., and Hartman, D. 2017. Evaluation of fungicide drench treatments for control of basil downy mildew, 2016. Plant Dis. Manag. Rep. 11:V031.

Roberts, P. D., Raid, R. N., Harmon, P. F., Jordan, S. A., and Palmateer, A. J. 2009. First report of downy mildew caused by a Peronospora sp. on basil in Florida and the United States. Plant Dis. 93:199.

Römer, P., Grosch, R., Kofoet, A., and Farahani-Kofoet, R. D. 2010. Selection of basil (Ocimum basilicum) breeding material resistant against downy mildew (Peronospora sp.) and tolerant to low temperature. Acta Hortic. 860:147-152.

Ronco, L., Rollan, C., Choi, Y. J., and Shin, H. D. 2008. Downy mildew of sweet basil (Ocimum basilicum) caused by Peronospora sp. in Argentina. New Dis. Rep. 18:14.

Šafránková, I., and Holkova, L. 2014. The first report of downy mildew caused by Peronospora belbahrii on sweet basil in greenhouses in the Czech Republic. Plant Dis. 98:1579.

Saude, C., Westerveld, S., Filotas, M., and McDonald, M. R. 2013. First report of downy mildew caused by Peronospora belbahrii on basil (Ocimum spp.) in Ontario. Plant Dis. 97:1248.

Scheufele, S. B., Campbell-Nelson, K., and Wick, R. L. 2015. Evaluation of copper fungicides for management of basil downy mildew in organic systems, 2014. Plant Dis. Manag. Rep. 9:V001.

Shrestha, S., Perla, E. E., Harlan, B. R., and Hausbeck, M. K. 2021. Field evaluation of basil cultivars for susceptibility to downy mildew, 2020. Plant Dis. Manag. Rep. 15:V066.
Silva, A. L., Mansur, P. S. C., Barreto, R. W., and Salcedo-Sarmiento, S. 2019. Peronospora belbahrii causes downy mildew on Ocimum basilicum in Brazil. Australas. Plant Dis. Notes 14:37.

Smith, S., and Urrea, K. 2018. First report of downy mildew caused by Peronospora belbahrii on sweet basil (Ocimum basilicum) in Arkansas. Plant Dis. 102:686.

Standish, J. R., Collins, H., and Quesada-Ocampo, L. M. 2020. Evaluation of fungicides for managing basil downy mildew epidemics in North Carolina, 2019. Plant Dis. Manag. Rep. 14:V032.

Standish, J. R., Collins, H., and Quesada-Ocampo, L. M. 2021. Evaluation of fungicides to manage epidemics of basil downy mildew in North Carolina, 2020. Plant Dis. Manag. Rep. 15:V058.

Voglmayr, H., and Piatek, J. 2008. Peronospora causing downy mildew disease of sweet basil newly reported in Cameroon. New Dis. Rep. 18:37.

Weston, W. H., Jr. 1920. Philippe downy mildew of maize. J. Agric. Res. 19:97-122.

Wick, R. L., and Brazee, N. J. 2009. First report of downy mildew caused by a Peronospora species on sweet basil (Ocimum basilicum) in Massachusetts. Plant Dis. 93:318.

Wyenandt, C. A. 2020. Evaluation of fungicide programs for management of downy mildew in sweet basil, 2017. Plant Dis. Manag. Rep. 14:V174.

Wyenandt, C. A., and Simon, J. E. 2014. Evaluation of foliar fungicides for management of downy mildew in sweet basil, 2013. Plant Dis. Manag. Rep. 8:V291.

Wyenandt, C. A., and Simon, J. E. 2020. Evaluation of biopesticides and conventional fungicides for management of downy mildew in sweet basil, 2019. Plant Dis. Manag. Rep. 14:V175.

Wyenandt, C. A., Simon, J. E., McGrath, M. T., and Ward, D. L. 2010. Susceptibility of basil cultivars and breeding lines to downy mildew (Peronospora belbahrii). HortScience 45:1416-1419.

Wyenandt, C. A., Simon, J. E., Pyne, R. M., Homa, K., McGrath, M. T., Zhang, S., Raid, R. N., Ma, L., Wick, R., Guo, L., and Madeiras, A. 2015. Basil downy mildew (Peronospora belbahrii): Discoveries and challenges relative to its control. Phytopathology 105:885-894.

Yarwood, C. E. 1937. The relation of light to the diurnal cycle of sporulation of certain downy mildews. J. Agric. Sci. 54:365-373.

Zhang, X., Low, Y. C., Lawton, M. A., Simon, J. E., and Di, R. 2021. CRISPR-editing of sweet basil (Ocimum basilicum L.) homoserine kinase gene for improved downy mildew disease resistance. Front. Genome Ed. 3:629-769. 